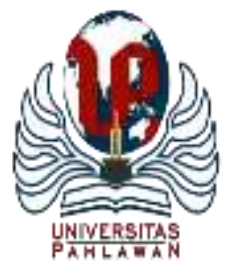

Edukatif : Jurnal Ilmu Pendidikan Volume 4 Nomor 1 Tahun 2022 Halm 456- 466 EDUKATIF: JURNAL ILMU PENDIDIKAN

Research \& Learning in Education

https://edukatif.org/index.php/edukatif/index

\title{
Analisis Persepsi Masyarakat Terhadap Pengolahan Pangan Lokal untuk Pencegahan Stunting di Jawa Timur
}

\author{
Anita $^{1 凶}$, Eko Sutrisno ${ }^{2}$ \\ Universitas Islam Majapahit, Indonesia ${ }^{1,2}$ \\ E-mail : anita@ unim.ac.id ${ }^{1}, \underline{\text { ekosudrun@ yahoo.com }}^{2}$
}

\begin{abstract}
Abstrak
Indonesia merupakan negara dengan tingkat stunting yang cukup tinggi. Pada tahun 2019 prevalensi stunting di Indonesia sebesar 27,7\%, dan data World Bank di tahun 2020 Indonesia menempati urutan prevalensi stunting pada urutan ke 115 dari 151. Stunting merupakan suatu keadaan dimana tinggi badan anak-anak lebih pendek dari anak anak seusianya. Stunting dapat mempengaruhi tumbuh kembang anak terutama kecerdasan anak. penelitian yang bertujuan untuk mengetahui persepsi masyarakat di Jawa Timur terhadap pengolahan pangan lokal untuk pencegahan stunting serta mengetahui faktor-faktor apa saja yang yang mempengaruhi konsumsi pangan lokal untuk pencegahan stunting. Penelitian menggunakan metode survey dengan lokasi di Jawa timur. Data yang digunakan dalam penelitian ini adalah data primer dan data sekunder. Jumlah responden dalam peneliitian ini ditentukan dengan rumus Slovin taraf $10 \%$ dan menggunakan teknik random. Hasil yang diperoleh adalah Persepsi masyarakat terhadap olahan pangan lokal untuk pencegahan stunting berada di kategori baik sedangkan hasil preferensi masyarakat berada di kategori biasa saja. Hasil regresi linier berganda menunjukan bahwa variabel pendidikan dan preferensi berpengaruh secara signifikan pada taraf $10 \%$ dan variabel pengetahuan berpengaruh signifikan pada taraf $5 \%$ sedangkan variabel pekerjaan, pendapatan dan persepsi tidak berpengaruh secara signifikan.
\end{abstract}

Kata Kunci : Persepsi, Pangan lokal, Stunting

\begin{abstract}
Indonesia is a country with a fairly high stunting rate. In 2019, the prevalence of stunting in Indonesia was $27.7 \%$, and World Bank data in 2020 showed that Indonesia ranked 115th out of 151. Stunting is a condition where a child's height is shorter than other children their age. Stunting can affect the growth and development of children, especially their intelligence. This study aims to determine the perception of people in East Java towards local food processing for stunting prevention and to find out what factors influence local food consumption for stunting prevention. The study used a survey method with locations in East Java. This study relied on both primary and secondary data. The number of respondents in this study was determined by the Slovin formula at a $10 \%$ level and using a random technique. The results obtained show that public perceptions of local food processing for stunting prevention are in a good category, while the results of community preferences are in the average category. The results of multiple linear regression showed that the education and preference variables had a significant effect at the 10\% level and the knowledge variable had a significant effect at the 5\% level. Meanwhile, occupation, income, and perception variables had no significant effect.
\end{abstract}

Keywords: Perception, Local Food, Stunting

Copyright (c) 2022 Anita, Eko Sutrisno

$\triangle$ Corresponding author

Email : anita@unim.ac.id

DOI : https://doi.org/10.31004/edukatif.v4i1.1765

ISSN 2656-8063 (Media Cetak)

ISSN 2656-8071 (Media Online)

Edukatif : Jurnal Ilmu Pendidikan Vol 4 No 1 Tahun 2022 p-ISSN 2656-8063 e-ISSN 2656-8071 


\section{PENDAHULUAN}

Indonesia merupakan negara dengan tingkat stunting yang cukup tinggi. Pada tahun 2019 prevalensi stunting di Indonesia sebesar 27,7\%, hal ini dapat diartikan 1 dari 4 balita (delapan juta lebih balita) mengalami stunting, sedangkan data World Bank di tahun 2020 Indonesia menempati urutan prevalensi stunting pada urutan ke 115 dari 151. Pandemi covid-19 menyumbang angka kemiskinan sehingga dapat dipastikan berpengruh pada tingkat penambahan stunting. Selain itu, efek pandemi Covid-19 yaitu terjadinya fenomenan stres pada keluarga (Jatira \& S, 2021). Penyumbang angka stunting terbesar yaitu daerah Nusa Tenggara Timur (NTT), Nusa Tenggaran Barat (NTB), Sulawesi, Kalimantan dan daerah timur di Indonesia. Stunting merupakan suatu keadaan dimana tinggi badan anak anak lebih pendek dari anak anak seusianya. Stunting terjadi karena kurangya asupan gizi pada anak dan dapat beresiko terganggunya tumbuh kembang anak/ pertumbuhan terhambat serta dapat menyebabkan penyakit seperti diare dan ISPA (Wellina et al., 2016). Kondisi anak stunting tidak selalu menggambarkan anak kecil dan kurus tetapi stunting dapat ditandai dengan badan gemuk namun pendek. Anak stunting yang tumbuh menjadi dewasa dapat mengakibatkan menurunya imun dalam tubuh sehingga rentan terkena penyakit tekanan darah tinggi, obesitas serta jantung, selain itu anak stunting memiliki IQ lebih rendah dibandingkan anak sehat pada umumnya yaitu selisih 11 point (Lestari et al., 2014).

Usia 1000 hari anak merupakan usia krusial untuk pencegahan anak stunting, dimulai dari kecukupan nutrisi ibu saat hamil dan pemberian ASI eksklusif serta setelah anak umur 6 bulan diberi makanan pendamping ASI atau disingkat MPASI. MPASI diberikan pada anak karena ASI tidak cukup untuk memenuhi kebutuhan si anak, terutama zat besi yang harus diperoleh dari MPASI. MPASI menentukan keberhasilan asupan zat besi, kekurangan zat besi dapat menyebabkan resiko diare serta infeksi saliran nafas serta alergi (Syaugi \& Istianah, 2019). Komposisi MPASI yang harus dipenuhi berupa unsur mikro atau pun unsur makro, diantara unsur makro adalah karbohidrat, protein serta lemak, sedangkan unsur mikro berupa vitamin dan mineral. Tentu saja semua itu harus kita berikan dalam bentuk makanan olahan yang disesuaikan dengan tekstur sesuai dengan usia bayi/anak. MPASI bervariasi, serta padat gizi serta harus hygiene agar terhindar dari kontaminasi bakteri (Mufida et al., 2015).

Nutrisi pada MPASI menentukan keberhasilan pencegahan stunting. Nutrisi tercukupi maka anak- anak akan dapat tumbuh kembang maksimal sesuai dengan usia mereka. Trend saat ini adalah pemberian MPASI dapat berupa MPASI terfortifikasi atau MPASI homemade. MPASI fortifikasi merupakan bahan MPASI yang sudah diolah oleh pabrik yang ditunjuk oleh pemerintah dan diawasi dalam pembuatannya sehingga ibu-ibu rumah tangga tinggal praktis dalam penyajiannya. Sedangkan MPASI homemade merupakan MPASI yang dibuat oleh ibu rumah tangga sendiri yang disesuaikan dengan menu yang akan diolah. Keberagaman pangan dapat mecegah kejadian stunting, balita dengan asupan makana yang kurang beragam memiliki resiko terjadi stunting 3,213 kali dibandingkan dengan balita dengan asupan makanan yang beragam.(Widyaningsih et al., 2018).

Bahan-bahan dalam pembuatan MPASI atau snack balita yang sering didengungkan di iklan-iklan $e$ commerce dengan pertimbangan kecukupan nutrisi, berasal dari produk produk impor seperti ikan salmon, sereal, unsalted butter, yoguhrt dll. Padahal jika kita melihat keragaman pangan Indonesia, potensinya sangat luas dan kategori cukup bagus dalam memenuhi kecukupan gizi untuk penanganan stunting. Saat ini banyak penelitian tentang snack balita dengan memanfaatkan potensi lokal seperti pemanfaatn mocaf-garut kombinasi hati menghasilkan biskuit dengan kandungan zat besi $14,05 \mathrm{mg} / 100 \mathrm{~g}$, artinya satu takaran biskuit d 22,8 g dapat mencukupi kebutuhan gizi zat besi balita sebesar 3,2 mg yang dibutuhkan harian (Agustia Friska Citra et al., 2017). Didukung dengan olahan pangan lokal lainnya yaitu biskuit berbahan dasar tepung tulang ikan malalugis (decapterus spp) mampu mningkatkan gizi anak bayi / balita stunting, terdapat perbedaan sebelum 
dan setelah intervensi konsumsi biskuit tepung ikan dapat dilihat dari tinggi anak. Hal ini karena dalam tepung ikan mengandung energi, karbohidrat, kalsium lemak serta protein (Sineke, 2020).

Daya terima pangan lokal untuk masyarakat baik untuk pencegahan stunting masih kurang, dibuktikan dengen penelitian uji daya terima kue pia subtitusi tepung tiram (crassostrea gigas) pada anak anak stunting menunjukan bahwa subtisusti $0 \%$ mempunyai daya terima lebih tinggi dibandingkan subtitusi tepung tiram $5 \%$ dan $10 \%$ (Mustamin et al., 2019). Kekurangan lain dari pemanfaatan pangan lokal untuk MPASI adalah daya simpan yang relatif pendek. Hasil penelitian pembuatan makanan biskuit MPASI tinggi fosfor berbahan dasar lokal dengan penambahan tepung wijen dan tepung kacang merah hanya memiliki daya simpan 42 hari saja (Marlina et al., 2019) Pemanfaatan kader posyandu merupakan bagian penting dalam keberhasilan pemanfaatan pangan lokal untuk pencegahan stunting ,seperti keberhasilan kader posyandu di perbatasan Indonesia dan PNG dapat dirasakan dengan timbulnya rasa kepedulian masyarakat akan gizi yang diperlukan untuk bayi/balita keluarga prasejahtera (Sumarsono et al., 2019). Selain itu orangtua yang dibekali pendidikan berbasis teknologi digital dapat meneruskan informasi dengan mudah dan fleksibel (Wulandari \& Ardianti, 2021). Hal ini dapat mendukung keberhasilan potensi pangan lokal untuk pencegahan stunting karena mudahnya akses informasi terkait nilai gizi dan teknik pengolahannya.

.Dari pemaparan diatas, pangan lokal sudah banyak dilakukan penelitian untuk dikaji kandungan gizi dan disesuaikan dengan tekstur untuk MPASI, namun daya terima masyarakat tentang pangan lokal dirasa masih kurang. Dalam hal ini, peneliti melakukan penelitian yang bertujuan untuk mengetahui persepsi masyarakat di Jawa Timur terhadap pengolahan pangan lokal untuk pencegahan stunting serta mengetahui faktor-faktor apa saja yang yang mempengaruhi konsumsi pangan lokal untuk pencegahan stunting sehingga harapan kedepan ditemukan solusi untuk keberhasilan pemanfaatan pangan lokal dalam upaya pencegahan stunting melalui daya terima masyarakat meningkat.

\section{METODE PENELITIAN}

Penelitian dilaksanakan selama 2 bulan yaitu bulan Oktober hingga November 2021. Penelitian menggunakan metode survey memanfaatkan media google form dengan pemilihan lokasi penelitian di Jawa timur, karena peneliti berdomisili di Jawa Timur. Data yang digunakan dalam penelitian ini adalah data primer dan data sekunder. Data primer diperoleh dari kuesioner tentang persepsi, preferensi, pengetahuan masyarakat terhadap pengolahan pangan lokal untuk pencegahan stunting sedangkan data sekunder diperoleh dari data pendukung tentang konsumsi pangan lokal di Jawa Timur. Penentuan jumlah responden menggunakan rumus Slovin taraf $10 \%$ dengan teknik random. Jumlah responden sebanyak 100 orang dengan kriteria wanita berusia 20-60 tahun, sudah menikah dan merupakan penduduk Jawa Timur. Kriteria tersebut dianggap dapat mewakili persepsi, preferensi masyarakat pada umumnya karena sebagai besar wanita yang mengolah pangan untuk anak-anaknya. Selain kriteria umur, kriteria sudah menikah juga dianggap sangat penting untuk menentukan keberhasilan pencegahan stunting dengan pangan lokal. Seorang perempuan ketika sudah menikah, baik belum memiliki atau sudah memiliki anak pasti memiliki perencanaan tentang nutrisi dan gizi yang akan diberikan kepada anaknya. sedangkan bagi ibu-ibu yang mempunyai anak sudah tumbuh dewasa setidaknya dapat diketahui pendapatnya tentang pengetahuan atau asumsi jenis pangan lokal untuk memenuhi kebutuhan nutrisi sebagai pencegahan stunting.

Data yang diperoleh dari hasil kuesioner akan diuji validitas dan reliabilitasnya guna mengetahui valid atau tidaknya intrumen pertanyaan untuk mengukur pengetahuan, persepsi dan preferensi responden. Reliable atau tidak nya instrumen pertanyaan yang dibandingkan dengan nilai cronbach alpha, sehingga jika instrument kuesioner reliable maka dapat dilakukan uji statsitik lanjut. Untuk menjawab tujuan pertama yaitu mengetahui pengetahuan masyarakat tentang ragam olahan pangan lokal untuk pencegahan stunting disajikan dengan deskriptif dari hasil kuesioner, dan untuk menjawab persepsi dan preferensi digunakan alat uji 
kategorisassi dengan metode Sugiyono, 2013 menggunakan garis kategori persepsi dan kategori preferensi. Sedangkan untuk menjawab tujuan ke empat yaitu faktor-faktor yang memepengaruhi konsumsi pangan lokal untuk pencegahan stunting dengan rumus regresi linier berganda dimana faktor dependennya konsumsi pangan lokal untuk mencegah stunting $(\mathrm{y})$ dan faktor independennya yaitu pendidikan $\left(\mathrm{x}_{1}\right)$, pekerjaan $\left(\mathrm{x}_{2}\right)$,pendapatan $\left(\mathrm{x}_{3}\right)$, pengetahuan $\left(\mathrm{x}_{4}\right)$, persepsi $\left(\mathrm{x}_{5}\right)$ dan preferensi $\left(\mathrm{x}_{6}\right)$. dilakukan uji $\mathrm{t}$ dan $\mathrm{f}$ dengan taraf $10 \% / \alpha 10$ guna mengetahui variabel apa saja yang paling mempengaruhi konsusmi pangan lokal untuk mencegah stunting. Tolak ukur keberhasilan penelitian ini adalah kesadaran masyarakat tentang pangan lokal untuk pencegahan stunting pada bayi/balita dan kesadaran akan pentingnya gizi yang beragam dan dapat diperoleh dari sekiatar yaitu berbagai jenis pangan lokal

\section{HASIL DAN PEMBAHASAN PENELITIAN}

Dari jumlah total 100 responden yang dipilih secara random diperoleh data sebagai berikut yaitu responden dengan umur 20-30 tahun sekitar 41,41\%, responden dengan umur 31-40 tahun sebanyak 26,26\%, responden dengan umur 41-50 tahun sebanyak 19,19\% dan responden dengan umur 51-60 tahun sebanyak $14,14 \%$. Pendidikan responden beragam mulai dari paling rendah berpendidikan SMP dan paling tinggi berpendikan S3. Berdasarkan hasil kuesioner, 100 responden berasal dari kota Surabaya, Mojokerto, Lamongan, Sidoarjo, Gresik, Trenggalek, Kediri, Madura, Jombang, Bojonegoro, Tuban serta Tulungagung.

Pekerjaan responden juga sangat bervariasi mulai dari Ibu rumah tangga, pegawai swasta, PNS, Pengusaha dengan pendidikan terakhir yaitu SMP sampai S3. Pada penelitian ini hasil kuesioner menunjuukkan bahwa responden dengan pendidikan terakhir S1 lebih banyak dibandingkan lainnya yaitu sebesar 46, 46\%, sedangkan berturut-turrut lainnya SMP sebesar 5,5, \%, SMA sebesar 18,18\%, D3 sebesar 7,7\%, S2 sebesar 15,15\%, dan S3 sebesar 9,9\%. Selain itu tingkap pendapatan per bulan dengan pendapatan 01 juta sebesar 29,29 \% (Sebagai besar pekerjaan Ibu rumah tangga), sedangkan pendapatan dengan range 1 juta - 2 juta sebesar 19,19\%, pendapatan dengan range 2 juta - 3 juta sebesar 19,19\% dan pendapatan dengan range lebih dari 3 juta sebesar 33,33\%. Sebanyak 98 responden sudah menikah dan mempunyai anak dengan rata-rata jumlah anak 1- 4 anak sedangankan 2 responden lainnya sudah menikah tetapi belum mempunyai anak. Selain itu $100 \%$ responden dalam penelitian ini yang dipilih secara acak berstatus perkawinan kawin (tidak ada responden dengan kategori cerai).

\section{Pengetahuan Responden}

Untuk mengetahui pengetahuan responden tentang pemberian nutrisi dari pangan lokal sebagai upaya pencegahan stunting, dalam penelitian ini menggunakan instrument pertanyaan diantaranya dapat di lihat pada Tabel 1.

Tabel 1. Hasil Data Instrumen Pertanyaan Tentang Pengetahuan Responden

\begin{tabular}{|c|c|}
\hline \multirow{2}{*}{ Pertanyaan } & Jawaban dalam presentase $\%$ \\
\hline & Tidak \\
\hline
\end{tabular}

Apakah ibu pernah/berencana memberikan bayi/anak-anak olahan karbohidrat selain beras seperti singkong, jagung, ubi jalar,sukun, ganyong dll 


\begin{tabular}{l}
\hline $\begin{array}{l}\text { Apakah ibu pernah/berencana memberikan } \\
\text { bayi/anak-anak olahan protein dari ikan lokal } \\
\text { seperti ikan kembung dan ikan lele? }\end{array}$ 92\% \\
\hline $\begin{array}{l}\text { Apakah sumber protein ikan salmon lebih bagus } \\
\text { daripada ikan lokal Indonesia? }\end{array}$ \\
\hline $\begin{array}{l}\text { Apakah ibu pernah /berencana memberikan } \\
\text { bayi/anak-anak sumber lemak tambahan dari gajih } \\
\text { ayam/sapi }\end{array}$ \\
$\begin{array}{l}\text { Apakah lemak tambahan dari Olive oil atau Butter } \\
\text { lebih bagus daripada lemak hasil sangrai dari gajih }\end{array}$ \\
$\begin{array}{l}\text { ayam/sapi } \\
\text { Apakah sumber pangan lokal ( karbohidrat, }\end{array}$ \\
$\begin{array}{l}\text { protein dan lemak ) mempunyai angka gizi yang } \\
\text { cukup untuk diberikan ke anak anak sebagai upaya } \\
\text { pencegahan stunting }\end{array}$ \\
\hline
\end{tabular}

Sebanyak $88 \%$ responden menjawab pernah/berencana memberikan bayi/anak-anak olahan karbohidrat selain beras seperti singkong, jagung, ubi jalar,sukun, ganyong dll. Responden memberikan sumber karbohidrat selain beras terdiri dari 4 jenis yaitu singkong, jagung, ubi jalar dan kentang. dengan bentuk olahan seperti: singkong dimasak menjadi kolak singkong, gatot, singkong kukus, getuk dan jemblem. Olahan lain bersumber dari jagung dimasak : dadar jagung, Pop Corn, jagung rebus, nasi jagung, sup jagung, bubur jagung, jasuke (jagung susu keju), dan pudding. Sedangkan karbohidrat sumber ubi rambat dimasak menjadi olahan : pudding dan ubi kukus. Sumber karbohidrat kentang dimasak menjadi berkedel kentang dan nugget kentang. Dari 100 responden, responden paling banyak menjawab memberikan asupan karbohidrat kepada bayi/anak-anak $60 \%$ berasal dari singkong. Singkong merupakan panga lokal sumber karbohidrat yang berpotensi untuk dikembangan menjadi sumber makanan untuk mendukung ketahanan pangan karena singkong mempunyai kandungan gizi yang tinggi diantaranya pati sebesar 35\%, serat kasar sebesar 2,5\%, protein sebesar $1 \%$, lemak sebesar $0,5 \%$, abu sebesar $1 \%$ dan sisanya $60 \%$ adalah air (Novitasari \& Arief, 2018). Singkong berpotensi sebagai pengganti nasi dimana setiap 100 gram singkong memiliki karbohidrat sebanyak 38 gram (Harsita Pradiptya Ayu \& Amam, 2019)

Hasil kuesioner tentang pernah/berencana memberikan bayi/anak-anak olahan protein dari ikan lokal seperti ikan kembung dan ikan lele untuk pencegahan stunting sebanyak 92\% responden menjawab iya sedangkan $8 \%$ menjawab tidak. Responden lebih banyak menjawab pernah / berencana memberikan ikan lokal lele dibanding dengan ikan kembung karena ikan kembung masih belum dikenal secara umum di masyarakat khususnya di daerah daerah bukan pesisir laut seperti Mojokerto, Jombang, Kediri. Tetapi berbeda dengan respon dari responden tentang pengetahuan gizi ikan salmon lebih bagus daripada ikan lokal, 50\% responden menjawab iya dan 50\% responden menjawab tidak. Artinya responden masih menganggap ikan salmon dengan harga yag relatif tinggi lebih baik gizinya dibandingkan dengan ikan lokal seperti kembung dan ikan lele. Faktanya kadar protein ikan lokal seperti ikan gabus 25,5\%, ikan bandeng 20,0\%, ikan lele $17,71 \%$ dan ikan emas $16,0 \%$ (Sari \& Rahmawati, 2018) Selian itu ikan lokal seperti Ikan kembung mengandung omega 3: 2,6gram sedangkan ikan salmon mengandung omega 3: 1,4g. Asam lemak dalam bentuk omega 3, 6 dan 9 merupakan asam lemak esensial yang harus dicukupi dari asupan mkanan. Asam lemak omega 3,6 dan 9 dibutuhkan untuk tumbuh kembang bayi dan anak anak guna memaksimalkan perkembangan otak serta membentuk kekebalan tubuh (Nurasmi et al., 2018). Dari hasil respon 100 responden tentang lemak tambahan, sebanyak 52\% responden memberikan lemak tambahan pada asupan makanan bayi/anak-anak berasal dari sumber lemak gajih ayam atau sapi sedangkan $48 \%$ menjawab tidak pernah 
461 Analisis Persepsi Masyarakat Terhadap Pengolahan Pangan Lokal untuk Pencegahan Stunting di Jawa Timur - Anita, Eko Sutrisno

DOI: https://doi.org/10.31004/edukatif.v4i1.1765

memberikan tambahan lemak. Hal ini sejalan dengan pengetahuan masyarakat tentang penggunaan olive oil atau butter pada makanan bayi/anak-anak dirasa lebih baik penggunaanya dibandingkan dengan lemak hasil dari gajih ayam atau sapi, dibuktikan dengan 59\% responden menjawab setuju menggunakan olive oil dan butter dan $41 \%$ menjawab tidak setuju. Lemak dari hewani seperti gajih ayam atau sapi tergolog lemak jenuh yang baik dan dibutuhkan oleh bayi/anak-anak untuk pertumbuhan otak. Bayi 0-2 tahun merupakan golden time, waktu emas untuk tumbuh kembang anak karena $80 \%$ perkembangan otak ada di fase tersebut. Salah satu asupan penting dalam perkembangan otak adalah nutrisi bersumber dari lemak karena $60 \%$ bagian otak terdiri dari lemak. Gajih ayam dapat disangrai untuk menghasilkan minyak, dimana minyak tersebut merupakan lemak jenuh yang dibutuhkan untuk bayi/anak-anak untuk memaksimalkan tumbuh kembang atau dapat menaikkan berat badan bayi/anak-anak. Hal ini dapat direkomendasikan kepada Ibu-Ibu masyarakat Jawa Timur bahwa dengan harga terjangkau dari sumber gajih ayam dapat mencukup kebutuhan lemak pada bayi/anak-anak, dibandingkan dengan harga olive oil atau butter yang relatif mahal.

\section{Persepsi Masyarakat terhadap Pangan Lokal Pencegahan Stunting}

Persepsi merupakan rangkaian proses sensori dimana terjadi proses pengindraaan dan penerimaan stimulus melalui panca indra manusia dan terjadi secara continue (Oktrisa et al., 2015). Pangan lokal merupakan suatu bahan pangan yang diproduksi atau dapat dengan mudah diperoleh dengan mudah disekitar masyarakat. Memaksimalkan pengolahan pangan lokal dengan menjaga gizi dan nutrisi yang dikandungnya sehingga pangan lokal mampu mencukupi kebutuhan gizi dan nutrisi bagi bayi/anak anak. Pangan lokal bersumber karbohidrat, protein dan lemak dapat dengan mudah dijumpai di setiap daerah karena setiap daerah memupunyai karakeristik tertentu misalnya daerah pesisir pantai mempunyai keuntungan melimpah ruah hasil ikan sehingga bisa digunakan untuk mencukupi kebutuhan protein hewani dari ikan untuk bayi/anak-anak. Sedangkan daerah non pesisir, dapat menggunakan protein hewani berupa ayam, telur daging sapi. Di daerah Jawa Timur, pangan lokal sumber karbohidrat selain beras misalnya singkong jagung ubi jalar mudah ditemukan di berbagai kota atau desa di Jawa Timur.

Pada peneilitian ini persepsi diukur dengan daerah kategorisasi, persepsi masyaratakt terhadap pangan lokal untuk pencegahan stunting menggunakan 6 item pertanyaan yaitu : harga, kemudahan untuk memeroleh, kemudahan mengolah, kandungan gizi, citra dan kepraktisan. Dari semua item pertanyaan untuk persepsi, rata rata responden menjawab beragam yaitu skor 1 : kurang skor 2: biasa saja dan skor 3: Baik. Tabel persepsi dapat dilihat pada Tabel 2. Dari hasil kategori persepsi diperoleh interval 400 sedangkan kriteria maksimum hasil mempunyai nilai 1800 dan jumlah skor responden diperoleh nilai sebesar 1568. Maka dapat ditulis dengan kategorisasi sebagai berikut : Gambar 1

Tabel 2. Instrumen Persepsi

\begin{tabular}{lllll}
\hline \multirow{2}{*}{ Instrumen Pertanyaan } & \multicolumn{3}{l}{ Jumlah Siswa } & \\
\cline { 2 - 5 } & $\mathbf{1}$ & $\mathbf{2}$ & $\mathbf{3}$ & Total (Jumlah siswa x Skor) \\
\hline Harga & 2 & 27 & 71 & 269 \\
\hline Kemudahan memperoleh & 2 & 4 & 94 & 292 \\
\hline kemudahan mengolah & 1 & 6 & 93 & 292 \\
\hline Kandungan gizi & 1 & 7 & 92 & 291 \\
\hline Citra & 6 & 55 & 39 & 233 \\
\hline Kepraktisan & 39 & 31 & 30 & 191 \\
\hline Total & & & & $\mathbf{1 5 6 8}$ \\
\hline
\end{tabular}




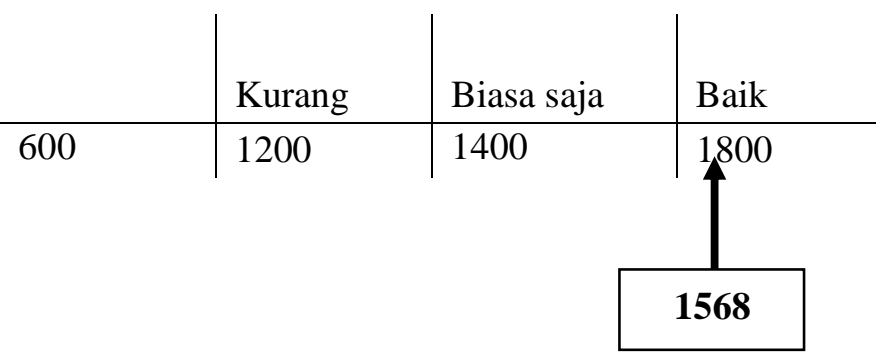

\section{Gambar 1. Daerah Kategorisasi Persepsi}

Dari hasil data yang sudah diolah di atas tentang persepsi, persepsi masyarakat terhadap pengolahan pangan lokal untuk pencegahan stunting masuk dalam kategori baik dengan jumlah nilai 1568 dari nilai maksimum sebesar 1800. Responden paling banyak menjawab suka pada instrumen harga, kemudahan memperoleh, kemudahan mengolah dan kandungan gizi, tetapi tidak demikian pada instrumen citra. Citra menunjukkan penampilan bayi/anak-anak kurang menyukai pangan lokal dibandingkan pangan kemasan/ pabrikan, 55\% responden menjawa biasa saja sedangkan 6\% lainnya menjawab tidak suka sisanya 33\% menjawab suka. Citra pangan lokal untuk pencegahan stunting kurang mendapatkan nilai bagus dibandingkan lainnya. Hal ini diduga karena kebiasaan serta pola hidup yang sudah terbiasa dengan mindset olahan karbohidrat adalah beras, protein dari salmon, ayam dan daging sapi. Selain itu didukung dengan instrument pertanyaan tentang kepraktisan, $39 \%$ respon menjawab pangan lokal untuk pencegahan stunting kurang praktis dibandingkan dengan makanan olahan pabrik/ kemasan pabrik, $31 \%$ menjawab biasa saja dan sisanya $30 \%$ menjawab suka. Masyarakat lebih memilih MPASI instan dengan aminan kepastian nutrisi tertera di label, hygiene serta keamanan produk dibandingkan dengan pangan lokal olahan sendiri (Nurselvi, 2019)

\section{Preferensi Masyarakat Terhadap Pangan Lokal Pencegahan Stunting}

Preferensi masyarakat dalam menentukan jumlah pembelian pangan lokal merupakan salah satu penentu konsumsi masyarakat terhadap oalahan pangan lokal untuk pencegahan stunting. Prefrensi juga dapat diartikan derajaat kesukaan pada setiap orang. Preferensi masyarakat terhadap olahan pangan lokal untuk penegahan stunting menggunakan indikator yaitu rasa, tekstur, aroma dan warna. Berdasarkan kategori setiap instrumen mempunyai interval 333 dengan nilai total adalah 1046 (Tabel 3) dan daerah kategori preferensi erada di garis biasa aja (Gambar 2).

Tabel 3. Instrumen Preferensi

\begin{tabular}{lllll}
\hline \multirow{2}{*}{ Instrumen Pertanyaan } & \multicolumn{4}{l}{ Jumlah Siswa } \\
\cline { 2 - 5 } & $\mathbf{1}$ & $\mathbf{2}$ & $\mathbf{3}$ & Total (Jumlah siswa x Skor) \\
\hline Rasa & 1 & 36 & 63 & 262 \\
\hline Tekstur & 2 & 12 & 86 & 284 \\
\hline Aroma & 5 & 45 & 50 & 245 \\
\hline Warna & 2 & 41 & 57 & 255 \\
\hline Total & & & & $\mathbf{1 0 4 6}$ \\
\hline
\end{tabular}




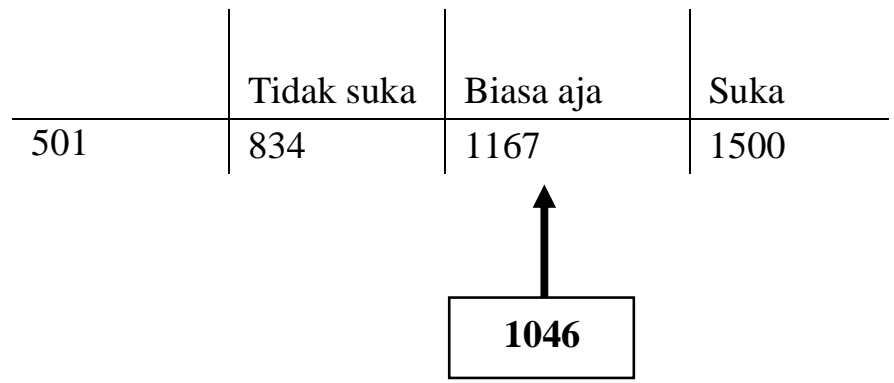

Gambar 2. Kategorisasi Instrument Preferensi

Hasil kategorisasi dari preferensi masyarakat dengan kategori rasa, tekstur aroma dan warna pangan lokal untuk pencegahan stunting mendapatkan hasil biasa saja. Untuk skor maksimum kategori suka adalah 1500. Rasa pada pangan lokal untuk bayi dan anak-anak lebih cenderung menyukai olahan produk lokal yang mempunyai rasa gurih dan manis, sehingga teknik pengolahan pangan lokal untuk bayi/anak-anak perlu ditingkatkan karena selam ini masyarakat hanya mengolah bahan lokal singkong diolah dengan metode di kukus dan direbus (singkong kukus, ubi kukus, jagung rebus) sehingga perlu divariasi dengan topping (susu kental manis, madu, vla dari putih telur) agar mempunyai rasa yang lebih variatif.

Tekstur dan aroma pada pangan lokal untuk pencegahan stunting sebagai besar masyarakat berpendapat bahwa bayi dan anak-anak menyukai tekstur olahan pangan lokal bertekstur renyah / crispy dengana aroma yang kuat, hal ini bisa disiasati dengan teknik pengolahan pangan lokal seperti pembuatan keripik, pastry kering dengan dipadukkan aroma kuat dari rempah, atau dipadukan dengan selai kacang yang kaya akan zat besi. Sedangkan ditambah dengan variasi warna, pangan lokal mempunyai jenis ungu dari ubi ungu, hijau dari pandan, orange dari wortel dan merah dari buat bit, putih dari tepung sagu, tepung singkong.

Preferensi masyarakata tentang pangan lokal untuk pencegahan stunting biasa aja dan masih dominan dengan pangan praktis pangan kemasan seperti pudding, bubus instan, kerupuk bayi/anak-anak instan. Untuk meningkatkan prefrensi olahan pangan lokal untuk bayi / anak-anak dapat divariasikan dengan pengolahan fortifikasi yaitu perpaduan antara pangan lokal protein hewani seperti lele dengan tepung singkong (Permatasari, et al 2021).

\section{Faktor-Faktor Yang Mempengaruhi Konsumsi Pangan Lokal Untuk Pencegahan Stunting}

Terdapat enam variabel yang digunakan dalam penelitian ini untuk mengetahui faktor-faktor yang mempengaruhi konsumsi pangan lokal untuk pencegahan stunting yaitu pendidikan orangtua (X1), pekerjaan (X2), pendapatan (X3), pengetahuan (X4), persepsi (X5) dan preferensi (X6). Berdasarkan hasil uji ANOVA dengan taraf $10 \%$ menunjukkan bahwa variable yang digunakan signifikan atau nilai $\mathrm{F}$ hitung lebih besar dari nilai tabel dan hasil uji t menunjukkan bahwa tingkat pendidikan, pengetahuan dan preferensi berpengaruh secara signifikan terhadap konsumsi pangan lokal untuk pencegahan stunting sedangkan variable pekerjaan, pendapatan dan persepsi tidak berpengaruh secara signifikan terhadap konsumsi pangan lokal untuk pencegahan stunting. Tabel Anova dapat dilihat pada Tabel 4 dan hasil uji coefficient / uji t dapat di lihat pada Tabel 5.

Tabel 5. ANOVA

\begin{tabular}{lllllll}
\hline \multirow{2}{*}{ Model } & & \multicolumn{2}{l}{ Sum } & of & & \\
Squares & df & Mean Square & F & Sig. \\
\hline 1 & Regression & 17.536 & 6 & 2.923 & 3.239 & $.006^{\mathrm{a}}$ \\
\cline { 2 - 7 } & Residual & 83.904 & 93 & .902 & & \\
\cline { 2 - 7 } & Total & 101.440 & 99 & & & \\
\hline
\end{tabular}


Tabel 6. Coefficient

\begin{tabular}{|c|c|c|c|c|c|c|}
\hline \multirow[b]{2}{*}{ Model } & & \multicolumn{2}{|c|}{ Unstandardized Coefficients } & \multirow{2}{*}{$\begin{array}{l}\text { Standardized } \\
\text { Coefficients } \\
\text { Beta }\end{array}$} & \multirow[b]{2}{*}{$\mathrm{t}$} & \multirow[b]{2}{*}{ Sig. } \\
\hline & & $\mathrm{B}$ & Std. Error & & & \\
\hline \multirow[t]{7}{*}{1} & (Constant) & -4.578 & 2.235 & & -2.048 & .043 \\
\hline & $\mathrm{X} 1$ & .853 & .331 & .384 & 2.573 & $* .012$ \\
\hline & $\mathrm{x} 2$ & -.478 & .398 & -.237 & -1.203 & .232 \\
\hline & $\mathrm{X} 3$ & -.472 & .398 & -.228 & -1.187 & .238 \\
\hline & $\mathrm{X} 4$ & 2.158 & .717 & .347 & 3.009 & $* * .003$ \\
\hline & $\mathrm{X} 5$ & .017 & .027 & .068 & .628 & .532 \\
\hline & X6 & .934 & .467 & .209 & 2.001 & $* .048$ \\
\hline
\end{tabular}

Nilai $\quad \mathrm{R}^{2} \quad 0,546$

* signifikan pada taraf $90 \%$

** siginfikan pada taraf $95 \%$

Berdasadarkan hasil analisis regresi linier maka diperoleh persamaan sebagai berikut :

$$
Y=-4578+0,857 X_{1}-0,478 X_{2}-0,472 X_{3}+2,158 X_{4}+0,17 X_{5}+0,934 X_{6}
$$

Keterangan :

$\mathrm{Y}=$ Konsumsi pangan lokal untuk pencegahan stunting (Kkal)

$\mathrm{X} 1 \quad=$ Pendidikan ibu (SMA sederjat / Sarjana)

$\mathrm{X} 2=$ Pekerjaan ibu(Formal / Informal)

$\mathrm{X} 3=$ Pendapatan (Rupiah/bulan)

$\mathrm{X} 4=$ Pengetahuan

$\mathrm{X} 5 \quad=$ Persepsi

X6 $=$ Preferensi

Dari hasil analisis diatas diperoleh nilai $\mathrm{R}$ square $\left(\mathrm{R}^{2}\right)$ 0,546\%, artinya adalah sebesar 54,6\% konsumsi pangan lokal untuk pencegahan stunting dapat dijelaskan oleh 6 variabel independen (pendidikan, pekerjaan, pendapatam, pengetahuan, persepsi dan preferensi) sedangkan sisanya sebesar $45,4 \%$ dipengaruhi oleh faktor lain diluar dari peneilitian ini.

Berdasarkan Tabel 6 dapat diketahui bahwa tingkat pendidikan, pengetahuan dan preferensi berpengaruh secara signifikan pada konsumsi pangan lokal untuk pencegahan stunting. Variabel tingkat pendidikan dan preferensi signifikan pada taraf $10 \%$ sedangkan variable pengetahuan signifikan pada taraf $5 \%$. Ketiga variabel ini sangat berkesinambungan,tingkat pendidikan orang tua diduga berpengaruh terhadap pengetahuan tentang tata cara pengolahan pangan lokal, kandungan gizi pangan lokal sehingga dapat menyebabkan preferensi dari pangan lokal rendah dan masyarakat jadi kurang beriminat untuk memberikan olahan pangan lokal sebagai upaya pencegahan stunting. Tingkat pendidikan mempengaruhi kejadian stunting, tingkat pendidikan semakin rendah semakin besar bayi/anak-anak beresiko stunting (Husnaniyah et al., 2020). Selain pendidikan formal, pendidikan informal seperti pelatihan dari kader posyandu juga sangat diperlukan 
untuk menambah pengetahuan tentang pengolahan pangan lokal sebagai upaya pencegahan stunting. Pelatihan ibu-ibu di desa -desa dapat menciptakan variasi pangan yang meliputi variasi rasa, aroma dan warna (Anita et al., 2021). Seorang ibu berperan penting dalam menentukan asupan nutrisi bayi/anak-anak, semakin luas pengetahuan yang dimilik oleh para ibu-ibu makan pengolahan bahan pangan lokal untuk pencegahan stunting bisa diolah secara variatif.

Sejalan dengan hal, peran ibu sangat penting dalam menentukan variasi menu, mengidentifikasi nutrisi, mengatur menu, mempersiapkan makanan untuk bayi/anak. Peran ibu sangat pentin utnuk penentuan faktor stunting, perilaku ibu, pengetahuan gizi ibu, pola asuh ibu merupakan faktor signifikan terjadinya stunting (Margawati \& Astuti, 2018). Dari pendapat -pendapat tersebut menunjukkan bahwa ketrampilan, pengetahuan seorang ibu sangat penting dalam mengolah pangan lokal untuk pencegahan stunting.

\section{KESIMPULAN}

Persepsi masyarakat terhadap olahan pangan lokal untuk pencegahan stunting dengan 6 variabel yaitu harga, kemudahan untuk memperoleh, kemudahan mengolah, kandungan gizi, citra dan kepraktisan berada di kategori baik. Variabel harga mendapatkan nilai lebih tinggi dibandingkan variable lainnya. Sedangkan hasil preferensi masyarakat dengan 4 variabel yaitu rasa, aroma, tekstur dan warna berada di kategori biasa saja. Hasil uji ANOVA dengan enam variabel penelitian diperoleh nilai $F$ hitung lebih besar dari F tabel dan hasil uji t menunjukan bahwa variable pendidikan dan preferensi signifikan / berpengaruh secara nyata pada taraf $10 \%$ dengan nilai signifikan berturut turut 0,012 dan $0,048<0,10$ sedangkan variable pengetahuan signifikan berpengaruh secara nyata pada taraf $5 \%$ dengan nilai signifikan $0,003<0,05$. Variabel pekerjaan, pendapatan dan persepsi tidak berpengaruh secara nyata. Persamaan regresi linier konsumsi pangan lokal untuk pencegahan stunting adalah : $\mathrm{Y}=-4578+0,857 \mathrm{X}_{1}-0,478 \mathrm{X}_{2}-0,472 \mathrm{X}_{3}+2,158 \mathrm{X}_{4}+0,17 \mathrm{X}_{5}+0,934 \mathrm{X}_{6}$.

\section{DAFTAR PUSTAKA}

Agustia Friska Citra, Subardjo Yovita Puri, \& Sari Hesti Permata. (2017). Pengembangan Biskuit MocafGarut Dengan Substitusi Hati Sebagai Alternatif Biskuit Tinggi Zat Besi Untuk Balita. Jurnal Gizi Dan Pangan, 12(2), 129-138. Https://Doi.Org/10.25182/Jgp.2017.12.2.129-138

Anita, Eko Sutrisno, Pinasthika R W Wiratara, \& Raida A Ifadah. (2021). Pelatihan Pembuatan Kerupuk "Debog Pisang” Dalam Upaya Peningkatan Pendapatan Keluarga Di Desa Konang Kecamatan Glagah Lamongan Jawa Timur. E-Amal Jurnal Pengabdian Masyarakat.

Harsita Pradiptya Ayu, \& Amam. (2019). Analisis Sikap Konsumen Terhadap Produk Olahan Singkong. Jurnal Sosial Ekonomi Dan Kebijakan Pertanian, 3(1):, 19-27.

Husnaniyah, D., Yulyanti, D., \& Rudiansyah, R. (2020). Hubungan Tingkat Pendidikan Ibu Dengan Kejadian Stunting. The Indonesian Journal Of Health Science, 12(1), 57-64. Https://Doi.Org/10.32528/Ijhs.V12i1.4857

Jatira, Y., \& S, N. (2021). Fenomena Stress Dan Pembiasaan Belajar Daring Dimasa Pandemi Covid-19. Edukatif: Jurnal Ilmu Pendidikan, 3(1), 35-43. Https://Doi.Org/10.31004/Edukatif.V3i1.187

Lestari, W., Margawati, A., \& Rahfiludin, Z. (2014). Faktor Risiko Stunting Pada Anak Umur 6-24 Bulan Di Kecamatan Penanggalan Kota Subulussalam Provinsi Aceh. Jurnal Gizi Indonesia (The Indonesian Journal Of Nutrition), 3(1), 37-45. Https://Doi.Org/10.14710/Jgi.3.1.126-134

Margawati, A., \& Astuti, A. M. (2018). Pengetahuan Ibu, Pola Makan Dan Status Gizi Pada Anak Stunting Usia 1-5 Tahun Di Kelurahan Bangetayu, Kecamatan Genuk, Semarang. Jurnal Gizi Indonesia (The Indonesian Journal Of Nutrition), 6(2), 82-89. Https://Doi.Org/10.14710/Jgi.6.2.82-89 
466 Analisis Persepsi Masyarakat Terhadap Pengolahan Pangan Lokal untuk Pencegahan Stunting di Jawa Timur - Anita, Eko Sutrisno

DOI: https://doi.org/10.31004/edukatif.v4i1.1765

Marlina, P. W. N., Maulianti, R. R. D. A., \& Fernandez, M. M. Y. (2019). Pengembangan Biskuit Mpasi Berbahan Dasar Berbagai Macam Tepung Sebagai Produk Inovasi Mpasi. Media Gizi Mikro Indonesia, 10(1), 27-38. Https://Doi.Org/10.22435/Mgmi.V10i1.587

Mufida, L., Widyaningsih, T. D., \& Maligan, J. M. (2015). Prinsip Dasar Makanan Pendamping Air Susu Ibu (Mp-Asi) Untuk Bayi 6 - 24 Bulan: Kajian Pustaka. 3(4), 6.

Mustamin, M., Asikin, H., \& Mursydati, M. (2019). Daya Terima Kue Pia Dengan Substitusi Tepung Tiram (Crassostrea Gigas) Pada Balita Stunting. Media Gizi Pangan, 26(1), 85. Https://Doi.Org/10.32382/Mgp.V26i1.1000

Novitasari, E., \& Arief, R. W. (2018). Analysis Of Chemical Characteristic Of Casava Flour From Klenteng And Casessart (Uj5) Varieties. Jurnal Penelitian Pertanian Terapan, 18(1), 52. Https://Doi.Org/10.25181/Jppt.V18i1.1227

Nurasmi, Sari Agus Purnama, \& Rusmiati. (2018). Analisis Kandungan Asam Lemak Omega 3, Omega 6 Dan Omega 9 Dari Ikan Lele (Clarias Sp) Pada Peningkatan Nutrisi Balita. Journal Of Borneo Holistic Health, 1 No 1, 5.

Nurselvi, N. (2019). Analisis Faktor Yang Mempengaruhi Konsumen Membeli Produk Makanan Pendamping Air Susu Ibu (Mp-Asi) Instan. Teknologi: Jurnal Ilmiah Dan Teknologi, 1(2), 138. Https://Doi.Org/10.32493/Teknologi.V1i2.3086

Oktrisa, T., Sayekti, W. D., \& Listiana, I. (2015). Persepsi, Preferensi Dan Pola Konsumsi Makanan Jajanan Berbasis Singkong Terhadap Remaja: Kasus Di Sman 2 Bandar Lampung Dan Sman 1 Tumijajar Tulang Bawang Barat. 3(2), 9.

Sari, D. K., \& Rahmawati, H. (2018). Kualitas Kimiawi Formula Mp-Asi Bubur Bayi Instan Berbasis Ikan Gabus Dengan Umur Simpan Tiga Bulan. Prosiding Seminar Nasional Lingkungan Lahan Basah, 3, 5.

Sineke, J. (2020). Pangan Lokal Tepung Tulang Ikan Malalugis (Decapterus. Gizido, 12(2), 12.

Sumarsono, A., Nurcholis, ., \& Winarsih, S. (2019). Program Kemitraan Masyarakat: Pemanfaatan Pangan Lokal Sebagai Sumber Asupan Gizi Bagi Balita Prasejahtera Daerah Perbatasan Di Kabupaten Merauke. Agrokreatif: Jurnal Ilmiah Pengabdian Kepada Masyarakat, 5(3), 258-265. Https://Doi.Org/10.29244/Agrokreatif.5.3.258-265

Syaugi, A. M., \& Istianah, I. (2019). Hubungan Asupan Zat Besi (Fe), Riwayat Mpasi Dengan Status Gizi Bb/U Pada Balita Usia 12-59 Bulan. Binawan Student Journal (Bsj), 1, 5.

Tria Astika Endah Permatasari1, Yudi Chadirin, Titiek S. Yuliani3, \& Sutrisno Koswara4. (N.D.). Pemberdayaan Kader Posyandu Dalam Fortikasi Pangan Organik Berbasis Pangan Lokal Sebagai Upaya Pencegahan Stunting Pada Balita. Vol.4 No.1 Oktober 2021. Http://Jurnal.Umj.Ac.Id/Index.Php/Jpmt

Widyaningsih, N. N., Kusnandar, K., \& Anantanyu, S. (2018). Keragaman Pangan, Pola Asuh Makan Dan Kejadian Stunting Pada Balita Usia 24-59 Bulan. Jurnal Gizi Indonesia (The Indonesian Journal Of Nutrition), 7(1), 22-29. Https://Doi.Org/10.14710/Jgi.7.1.22-29

Wulandari, R., \& Ardianti, S. D. (2021). Tantangan Digitalisasi Pendidikan Bagi Orang Tua Dan Anak Di Tengah Pandemi Covid-19 Di Desa Bendanpete. Edukatif: Jurnal Ilmu Pendidikan Research \& Learning In Education Https://Edukatif.Org/Index.Php/Edukatif/Index, 3(6), 13. 